\title{
Evaluation of the Frequency of Prolonged Fevers and Exploration of Their Etiologies in the Internal Medicine Department of the Point "G" University Hospital in Bamako from 2009 to 2013
}

\author{
Abdel Kader Traoré1, Assétou Soukho Kaya¹, Djenebou Traoré1, Djibril Sy¹, \\ Youssouf Fofana², Ibahima Amadou Dembélé1, Mamadou Saliou', Boua Daoud Camara ${ }^{3}$, \\ Karim Dao', Mamadou Cissoko1, Kaly Kéïta1, Barry Boubacar Sangaré1, Mamadou Mallé1, \\ Alassane A. Doumbia', Nagou Tolo', Hadiza A. Kaïlou' ${ }^{1}$, Mamadou Dembélé1, \\ Hamar Alassane Traoré1 \\ ${ }^{1}$ Deparment of Internal Medicine, University Hospital of Point “G”, Bamako, Mali \\ ${ }^{2}$ Department of Internal Medicine of Children and Mothers, Le Luxembourg University Hospital, Bamako, Mali \\ ${ }^{3}$ Internal Medicine Service, Nianankoro Fomba Hospital, Ségou, Mali \\ Email:traoreak@gmail.com, assetousouko@yahoo.fr, hassiramadydembele@yahoo.fr, traorhamaralassane@yahoo.fr
}

How to cite this paper: Traoré, A.K., Kaya, A.S., Traor, D., Sy, D., Fofana, Y., Dembélé, I.A., Saliou, M., Camara, B.D., Dao, K., Cissoko, M., Kéita, K., Sangaré, B.B., Mallé, M., Doumbia, A.A., Tolo, N., Kaïlou, H.A., Dembélé, M. and Traoré, H.A. (2019) Evaluation of the Frequency of Prolonged Fevers and Exploration of Their Etiologies in the Internal Medicine Department of the Point "G" University Hospital in Bamako from 2009 to 2013. Open Journal of Internal Medicine, 9, 97-103.

https://doi.org/10.4236/ojim.2019.93014

Received: June 26, 2019

Accepted: September 3, 2019

Published: September 6, 2019

\begin{abstract}
Objective: The aim was to evaluate the frequency of prolonged fevers and to determine their etiologies. Methods: We carried out a cross-sectional study extending from the period of 2009 to 2013 in the Internal Medicine department of the "G" Point University Hospital in Bamako. Included were all records of hospitalized patients with a central temperature greater than $37^{\circ} \mathrm{C}$ in the morning and $37^{\circ} \mathrm{C}$ in the evening, resting for 15 minutes, fasting for more than 2 hours, and absence of antipyretic treatment. We include all the patients of the study period with fever greater than $37.5^{\circ} \mathrm{C}$ in the morning and $37.8^{\circ} \mathrm{C}$ in the evening, resting for 15 minutes, fasting for more than 2 hours, and absence of antipyretic treatment, which have more than 21 days and measured on several occasions. The data were collected on a survey sheet. Data entry and analysis was done on SPSS software. Results: We recorded 243 fever cases out of 2155 hospitalizations, a prevalence rate of $11.2 \%$. There were 128 men and 115 women with an average age of 43 years (range, 15 to 84 years), a modal class of 37 to 47 years, and a sex ratio of 1.11. The infectious etiologies accounted for $81 \%$ followed by neoplastic causes $09.6 \%$ and inflammatory $01.2 \%$ of cases. HIV infection was found in $26.4 \%$ of patients, malaria $13.5 \%$ and urinary tract infections $10.2 \%)$. Gram negative bacilli $88 \%$ consisted mainly of Escherichia coli (56\%) and Klebsiella pneumoniae (20\%).
\end{abstract}


Copyright $\odot 2019$ by author(s) and Scientific Research Publishing Inc. This work is licensed under the Creative Commons Attribution International License (CC BY 4.0).

http://creativecommons.org/licenses/by/4.0/

\section{Keywords}

Fever Acute, Prolonged Fevers, Frequency, Etiologies, Internal Medicine, Mali

\section{Introduction}

Fever is the rise of central temperature, being higher than $37.5^{\circ} \mathrm{C}$ in the morning and higher than $37.8^{\circ} \mathrm{C}$ in the evening, resting for 15 minutes, fasting for more than 2 hours, and absence of antipyretic treatment [1].

It may be:

- Acute: $<5$ days.

- Recently acute: Having a fever more than 5 days and less than 20 days.

- Prolonged: Having a fever more than 21 days.

Fever is the most common symptom of infectious diseases: Among 15\% to $20 \%$ of urgent consultation, $40 \%$ of causes of infections came from Europe and $90 \%$ from Africa [2].

In Mali, Haïdara [3] carried out a study focusing on malaria in febrile syndrome in the department of internal medicine of Point G University central hospital from 1988 to 1989 and found 335 cases of fever.

It still was a challenge for a physician to diagnose the prolonged fever. Actually, because of the development of technology, it is thought that unexplained prolonged fever has been a thing of the past, while it is not.

Unexplained prolonged fever or fever of unknown origin was still a typical condition of internal medicine for Anglo-Saxons and a common reason of hospitalization (about one person per month) [4].

According to the opinion of Petersdorf in 1961, the conception of unexplained prolonged fever became a typical idea, which was a kind of fever with the temperature more than $38.3^{\circ} \mathrm{C}$ lasting for more than three (3) weeks as well as unexplained causes after the exploration of one-week hospitalization [5].

In 2001, Durack and Street revisited this definition. They advised replacing the 3rd standard by the following methods: After getting the result of preliminary explorations including multi-culturing, serologic examination, and imaging, the cause was still inexplicit. They also advised dividing this fever into 4 types: Classic type with neutropenia, in hospital, and patient of ADIS because the etiological profiles were significantly different [6].

Finally, others were called FRI, a fever prolonging 2 to 3 weeks. Although routine and assistant clinic examinations had been carried out [7], its cause still wasn't found.

In Congo Brazza, G. Moyen, etc. found [8] 168 cases of prolonged fever among children from 1989 to 1991 . What was rarer was that unexplained prolonged fever was more anxious, especially when fever appeared as a single symptom or the main symptom. Diagnosing it was one feature of physicians, but it 
was also a challenge (More than 200 causes, lack of algorithmic decisions and recommendations, and requests of rapid recovery of patients' body) [9].

In Africa, contrasted with the prolonged fever of children [10], prolonged fever of adults was less studied. This work was carried out with Africa as the background. Its purpose was to research fever, particularly prolonged fever of adults. The target was to evaluate the frequency of fever especially prolonged fever and to confirm the cause.

\section{Materials and Methods}

We initiated a transversal study with retrospectively collecting data in to the department of internal medicine of Point G university central hospital in Bamako from 2009 to 2013. We include all the patients of the period of study with prolonged fever, which are fever greater than $37.5^{\circ} \mathrm{C}$ in the morning and $37.8^{\circ} \mathrm{C}$ in the evening, resting for 15 minutes, fasting for more than 2 hours, and absence of antipyretic treatment, which have more than 21 days [1]. All patients with fever witch not respect the inclusion criteria have been excluded. We use axillary temperature which was the usually measuring method of the evaluation of the temperature at the moment of the study.

For all patients, we collected variables of social demography, clinical variables, biological, radiological and functional explorations regarding to the etiological the hypothesis.

Data analysis has been done with SPSS 12 software.

\section{Results}

We collected 243 cases of fever among 2155 cases of hospitalized patients in 5 years, so the prevalence was $11.2 \%$, including 128 men and 115 women, with an average age of 43 years (ranging from 15 to 84 years). The modal age ranged from 37 to 47 years, and the sex ratio was 1.11 (Table 1).

Among 243 cases of fever, HIV infection ranked first, with 59 cases, followed by 30 cases of malaria and 25 cases of urinary tract infection (Table 2).

HIV infection accounted for $26.4 \%$ of cases of fever, and $2.7 \%$ of hospitalized patients in the department of Internal Medicine. (We had counted 52 cases of single infection of HIV, 7 cases of morbid relation: 4 cases related to urinary

Table 1. Divide according to age and gender.

\begin{tabular}{|c|c|c|c|c|c|c|c|c|}
\hline & \multicolumn{7}{|c|}{ Age of the patient } & \multirow[b]{2}{*}{ Total } \\
\hline & $\begin{array}{c}15-25 \\
\text { years } \\
\text { old }\end{array}$ & $\begin{array}{c}26-36 \\
\text { years } \\
\text { old }\end{array}$ & $\begin{array}{c}37-47 \\
\text { years } \\
\text { old }\end{array}$ & $\begin{array}{c}48-58 \\
\text { years } \\
\text { old }\end{array}$ & $\begin{array}{c}59-69 \\
\text { years } \\
\text { old }\end{array}$ & $\begin{array}{c}70-80 \\
\text { years } \\
\text { old }\end{array}$ & $\begin{array}{c}81 \text { - } 91 \\
\text { years } \\
\text { old }\end{array}$ & \\
\hline Male & 17 & 27 & 35 & 35 & 5 & 8 & 1 & 128 \\
\hline $\begin{array}{l}\text { Gender } \\
\text { Female }\end{array}$ & 21 & 33 & 26 & 22 & 9 & 4 & 0 & 115 \\
\hline Total & 38 & 60 & 61 & 57 & 14 & 12 & 1 & 243 \\
\hline
\end{tabular}


Table 2. Etiology of fever divided by year of hospitalization.

\begin{tabular}{|c|c|c|c|c|c|c|c|}
\hline \multirow{2}{*}{ Pathology } & \multicolumn{5}{|c|}{ Year of hospitalization } & \multirow{2}{*}{ Total } & \multirow{2}{*}{$\begin{array}{c}\text { Percentage } \\
\%\end{array}$} \\
\hline & 2009 & 2010 & 2011 & 2012 & 2013 & & \\
\hline HIV infection & 7 & 9 & 12 & 10 & 14 & 52 & 23.3 \\
\hline Malaria & 4 & 6 & 2 & 2 & 7 & 21 & 09.4 \\
\hline Diabetic foot & 2 & 6 & 4 & 5 & 4 & 21 & 09.4 \\
\hline Tuberculosis & 2 & 2 & 2 & 4 & 2 & 12 & 5.4 \\
\hline Solid tumors & 1 & 1 & 6 & 0 & 4 & 12 & 5.4 \\
\hline Septicemia & 3 & 2 & 3 & 0 & 0 & 8 & 3.6 \\
\hline Meningitis & 0 & 2 & 1 & 1 & 2 & 6 & 2.8 \\
\hline Urinary tract infections & 0 & 0 & 0 & 1 & 2 & 3 & 1.3 \\
\hline Urinary tract infections + diabetes & 1 & 1 & 3 & 1 & 6 & 12 & 5.4 \\
\hline Urinary tract infections + malaria & 1 & 0 & 2 & 0 & 3 & 6 & 2.8 \\
\hline Urinary tract infections + HIV & 1 & 2 & 0 & 0 & 1 & 4 & 1.8 \\
\hline Malaria + HIV & 0 & 1 & 0 & 1 & 1 & 3 & 1.3 \\
\hline Hodgkin's disease & 0 & 1 & 2 & 0 & 1 & 4 & 1.8 \\
\hline $\begin{array}{l}\text { Non-Hodgkin's malignant } \\
\text { lymphoma }\end{array}$ & 0 & 0 & 1 & 0 & 2 & 3 & 1.3 \\
\hline Multiple myeloma & 0 & 1 & 0 & 1 & 0 & 2 & 0.9 \\
\hline Leukocytoclastic vasculitis & 0 & 0 & 0 & 1 & 0 & 1 & 0.4 \\
\hline Other & 7 & 12 & 13 & 11 & 10 & 53 & 23.7 \\
\hline Total & 29 & 46 & 51 & 38 & 59 & 223 & 100.00 \\
\hline
\end{tabular}

NOTE: The solid tumors consist of: Prostatic cancer (5). Bladder cancer (2). Liver cancer (2). Mammary cancer (1). Pancreatic cancer (1). Gastric cancer (1).

tract infection and 3 cases related to malaria.

Malaria ranked second, accounting for $10.2 \%$ of cases (25/243). There were 21 cases of single malaria, 6 cases related to urinary tract infection and 3 cases related to HIV infection.

Urinary tract infection ranked third, 3 cases of single urinary tract infection and 22 cases related to its morbid: 12 cases related to diabetes, 6 cases related to malaria and 4 cases related to HIV. Germs frequently found were: Escherichia coli (56\%) and Klebsiella pneumoniae (20\%). We have found one case of urinary tuberculosis (Table 3).

Among 23 remained cases of diagnoses of prolonged fever, the main cause was neoplastic causes (39.4\%) and infections.

Other cases of fever were caused by varies diseases (hematonosis, septicemia, meningitis, and systemic diseases. Causes of prolonged fever were exhibited in Table 4 according to the year of hospitalization.

There were 10 patients who died without certainly diagnosis after being in hospital 2 to 4 days. The infective cause was found in $81 \%$ of cases, and the main cause was bacterial infection: with it accounted for $47 \%$ of cases (Table 4 ). The cause of prolonged fever was still not determined in 10 cases (43.4\%). 
Table 3. Distribution of urinary germs according to their morphology.

\begin{tabular}{ccccc}
\hline Morphology & Bacterial species & Frequencies & \multicolumn{2}{c}{ Percentage \% } \\
\hline Gram Bacillus & Escherichia coli & 14 & 56 & \\
Negative & Klebsiella pneumoniae & 5 & 20 & 88 \\
& Pseudomonas æruginosa & 3 & 12 & \\
Gram Cocci & Coagulase negative & 2 & 8 & 12 \\
Positive & staphylococcus & 2 & 4 & \\
& Staphylococcus aureus & 1 & \multicolumn{2}{c}{100.00} \\
\end{tabular}

Table 4. Causes of fever.

\begin{tabular}{cccc}
\hline \multicolumn{2}{c}{ Causes } & Frequency & Percentage \% \\
\hline \multicolumn{2}{c}{ Infectious causes } & 197 & 81 \\
Neoplastic causes & Solid tumors & 12 & 9.6 \\
& Hematologic & 11 & 1.2 \\
Inflammatory causes & 3 & 8.2 \\
\multicolumn{2}{c}{ Without diagnosis } & 20 & 100.00 \\
\hline \multicolumn{2}{c}{ Total } & 243 &
\end{tabular}

\section{Discussion}

We include in 5 years 243 cases of prolonged fever among 2155 cases. The prevalence was $11.2 \%$ and the average age was 43 years (ranging from 15 to 84 years). The modal age ranged from 37 to 47 years, and the sex ratio was 1.11 .

In our study, 59 of the 243 fever cases were diagnosed as HIV, accounting for 26.4\%. This kind of infection accompanied with typhoid was the fourth largest cause of hospitalization for fever [3] of internal medicine in 1989. However, it became the largest cause of hospitalization for fever 24 years later. It was not surprising. Nowadays, the rate of disease and newly infection of HIV in Mali is very high. Consequently, according to the data of UNAIDS, 70\% of the 34 million people contracting HIV (estimated by WHO in 2010) lived in the south of the Sahara Desert in Africa [10]. It was estimated that there were 180 thousand HIV patients in Mali in 2008, 25,542 of which were having therapy [11].

Ordinary people who went for advice about malaria accounted for $37.5 \%$, children from 1 to 4 accounting for $46.9 \%$ [12]. Malaria was the main cause of death for children from 0 to 5 . It was also the main cause of death for children under 5 years old and disease for most people [12]. In our study, it ranked the same position in internal medicine as 24 years before [3], including the $2 \mathrm{nd}$, but the annual prevalence felt a little. It accounted for $13.5 \%$ of fever cases.

Abou [13] also took it as the second largest cause of fever in Burkina, after children acute respiratory infections. Assi [14] took it as the third largest cause, after the neonatal pathology of pediatrics in Cocody University Central Hospital and acute respiratory infections. 
Urinary tract infection kept the position 24 years before like malaria. It was the third largest cause of hospitalization for fever in internal medicine [3]. It accounted for $10.2 \%$ of the causes of fever. Urinary tract infection was more common to be found in diabetes patients than people not contracting diabetes [15]. The duration and the type of diabetes didn't influence on the happening of diabetes possibly. In our cases, 12 cases were relative to diabetes. In Traoré [16]'s study, 29 cases were relative to diabetes. As most researchers' thoughts, Escherichia coli and Klebsiella pneumoniae are the most common independent creatures [17] [18]. Our study confirmed this observation. Only these two kinds of bacteria accounted for $76 \%$. The proportion was comparable to that in the research of Traoré [16], which was 75\%. Although urinary tract tuberculosis was rarely to be seen, one case was found. 2 cases were found in Traoré [16].

From 1950 to 1960, prolonged fever for an unknown reason was divided into four types: Infection, the formation of a tumor, inflammatory disease, and other mentioned reasons. The fifth category was the so-called undiagnosed fever [17].

\section{Conclusion}

The cause of ordinary fever is mainly infection, especially HIV virus, malaria, and urinary tract infection. HIV-HIV virus is rather not a kind of controlled virus. It is still a significant public hygiene problem worldwide. To reduce its effect, it is necessary to strengthen the cognition of changes in behaviors. For cases of prolonged fever, the main cause is still the tumor. However, the proportion of infectious cause in our series studies is very low, and infection is still a cause of disease in our country. Therefore, police interrogation remains essential. The purpose of it is to track all the clues, including geographical sources.

\section{Conflicts of Interest}

The authors declare no conflicts of interest regarding the publication of this paper.

\section{References}

[1] Bariety, M., Bonnio, T.H. and Bariety, J. (1980) Fever. In: Bariety, M. and Bonnio, T.H., Eds., Summary of Symptomatology, 7th Edition, Masson, Paris, 36-40.

[2] Beaufils, F. and Bourrillon, A. (1985) Fever of Infants. Archives Francaises de Pediatrie, 42, 53-61.

[3] Haïdara, S.A., Doumbo, O., Traoré, H.A., Koita, O., Dembélé, M., Dolo, A., Pichard, E. and Diallo, A.N. (1991) The Position of Malaria in the Fever Syndrome of Internal Medicine of Point G Hospital (Results of System Research for One Year). Medecine d Afrique Noire, 38, 110-117.

[4] Likuni, Y., Okada, J., Kondo, H. and Kashiwazaki, S. (1994) Current Fever of Unknown Origin 1982-1992. Internal Medicine, 33, 67-73. https://doi.org/10.2169/internalmedicine.33.67

[5] Petersdorf, R.G. and Beeson, P.B. (1961) Fever of Unexplained Origin: Report on 100 Cases. Medicine (Baltimore), 40, 1-30. 
https://doi.org/10.1097/00005792-196102000-00001

[6] Durack, D.T. and Street, A.C. (2001) Fever of Unknown Origin: Re-Eliminated and Re-Defined. Current Clinical Topics in Infectious Diseases, 11, 35-51.

[7] Dinarello, C. and Wolff, S.M. (1985) Fever of Unknown Origin in Mandell Douglas and Bennett. Principles and Practice of Infectious Diseases. 2nd Edition, Churchill Livingston, New York, 339-347.

[8] Moyen, G., Okandze-Elanga, J.P. and Nzingoula, S. (1993) Children Prolonged Fever. About 168 Cases Extracted by Brazzaville University Central Hospital. Medecine d Afrique Noire, 40, 375-379.

[9] Dupond, J.-L. (2006) Prolonged Fever for Unknown Reasons: Tactic, Strategy. La Revue de Médecine Interne, 27, 266.

[10] UNAIDS/WHO (2010) Update on the Global AIDS Epidemic. Geneva. http://www.unaids.org

[11] Samake, S., Traoré, S., et al. (2006) The Survey of Population and Hygiene. Mali-IV (EDS-IV). Ministry of Health. Mali EDS-MIV, $456 \mathrm{p}$.

[12] Anonymous Local Health Information System Yearbook of Mali in 2007.

[13] Baudon, D., Ouédrago, L., Galaud, B. and Gazin, P. (1988) The Study of the Incidence Rate of Malaria in Burkina Faso Hospital. Med Trop, 48, 9-13.

[14] Adou, A.J., Cabannes, R., Assale, G. and Kouame, K.J. Malaria and Pediatrics of the South of Sahara Desert in Africa. Africa Medical Publications in 1989. 38-41.

[15] Gin, H. (1993) Infection and Diabetes. La Revue de Médecine Interne, 14, 32-38. https://doi.org/10.1016/S0248-8663(05)82519-6

[16] Traoré, H.A., Kéita, B., Diallo, F.S., Dembélé, M., Diallo, D., Diallo, A.N. and Pichard, E. (1994) The Clinical and Bacteriological Study of Urinary Tract Infection in Internal Medicine of Point G National Hospital. Medecine d Afrique Noire, 41, 336-342.

[17] Hot, A. and Ninet, J. (2006) Fevers for Unknown Reasons: The Paradox That Is Harder and Harder to Diagnose. Revue de Médecine Interne, 27, 255-258.

[18] Sow, M. and Zoung, D.J. (1989) La pyonéphrose: Aspects cliniques, bactériologiques et thérapeutiques à propos de 92 cas traités à l'Hôpital Central de Yaoundé (Cameroun). Medecine d Afrique Noire, 36, 701-703. 